Journal of Extension Education

Vol. 28 No. 2, 2016

\title{
Adoption of Kerala Agricultural University Recommended Practices of Amaranthus and Vegetable Cowpea
}

\author{
K.K. Anju ${ }^{1}$ and V.B. Padmananabhan ${ }^{2}$
}

\begin{abstract}
The study was conducted in Thiruvananthapuram district of Kerala. Ninety farmers engaged in commercial cultivation of amaranthus and vegetable cowpea were selected through three stage random sampling procedure. Ten independent variables were selected based on judges' relevancy rating. Majority of the respondents belonged to medium category with respect to adoption. In the case of amaranthus growers, four variables, namely, contact with extension agency, scientific orientation, innovativeness and mass media exposure were found to be significantly and positively related to adoption. Education, scientific orientation and innovativeness were found to be significantly and positively related to adoption in the case of vegetable cowpea growers.
\end{abstract}

Keywords : Adoption, Amaranthus, Vegetable cowpea, Kerala.

\section{INTRODUCTION}

Amaranthus and vegetable cowpea are two important crops commercially cultivated by vegetable growers in Kerala. To increase the production of these crops, a package of practices has been developed by Kerala Agricultural University (KAU). For attaining sustainable yield, timely execution of the recommended package is essential. But majority of the farmers are not adopting the recommended package of practices for amaranthus and vegetable cowpea. With this background, the study was undertaken with the following objectives.

1. To study the profile characteristics of commercial growers of amaranthus and vegetable cowpea in Thiruvananthapuram district of Kerala

2. To study the extent of adoption of KAU varieties and selected recommended practices of amaranthus and vegetable cowpea.

3. To study the relationship of profile characteristics of growers with adoption.

\section{METHODOLOGY}

For the present study, Thiruvananthapuram district of Kerala was selected because of the presence of College of Agriculture, Vellayani Thiruvananthapuram from where high

1- PG Scholar \& 2 - Professor, Department of Agricultural Extension, College of Agriculture, Kerala Agricultural University, Vellayani - 695522, Thiruvananthapuram, Kerala. 
yielding varieties of amaranthus and vegetable cowpea are being released and distributed. Selection of respondents was through three stage random sampling procedure. In the first stage, from the list of blocks having larger area under amaranthus and vegetable cowpea cultivation, three blocks were randomly selected, namely, Nemom, Kazhakoottam and Vamanapuram from the eleven blocks of Thiruvananthapuram district. In the second stage, in each block, from the list of panchayats having larger area under amaranthus and vegetable cowpea cultivation, one panchayat was selected randomly, namely, Kalliyoor, Kazhakoottam and Pullampara. In the third stage, from the lists of farmers engaged in commercial cultivation of amaranthus and vegetable cowpea, fifteen amaranthus growers and fifteen vegetable cowpea growers were selected randomly, thus making a total of ninety farmers. Ten independent variables were selected based on judges' relevancy rating which were measured using suitable devices. To study the rate of adoption, a list of practices was prepared based on the details given in KAU (2011). The extent of adoption was calculated using adoption quotient for measuring adoption behaviour as developed by Chattopadhyay (1963) and modified by Singh and Singh (1967).

\section{FINDINGS AND DISCUSSION}

The distribution of amaranthus growers and vegetable cowpea growers based on their profile characteristics is provided in Table 1.

Table 1.

Distribution of Amaranthus Growers and Vegetable Cowpea Growers based on their Profile Characteristics

\begin{tabular}{|c|c|c|c|c|c|c|}
\hline \multirow{2}{*}{$\begin{array}{l}\text { S1. } \\
\text { No }\end{array}$} & \multirow{2}{*}{$\begin{array}{c}\text { Profile } \\
\text { Characteristics }\end{array}$} & \multirow{2}{*}{ Category } & \multicolumn{2}{|c|}{ Amaranthus } & \multicolumn{2}{|c|}{ Vegetable cowpea } \\
\hline & & & Frequency & Percentage & Frequency & Percentage \\
\hline \multirow{3}{*}{1.} & \multirow{3}{*}{ Age } & $\begin{array}{l}\text { Young } \\
\text { age (< } 35 \\
\text { years) }\end{array}$ & 0 & 0 & 0 & 0 \\
\hline & & $\begin{array}{l}\text { Middle } \\
\text { age (35 } \\
-55 \text { years) }\end{array}$ & 32 & 71.11 & 30 & 66.67 \\
\hline & & $\begin{array}{l}\text { Old age ( } \\
>55 \text { years) }\end{array}$ & 13 & 28.89 & 15 & 33.33 \\
\hline
\end{tabular}


Adoption of Kerala Agricultural University Recommended Practices of Amaranthus and Vegetable Cowpea

Table 1 contd.

\begin{tabular}{|c|c|c|c|c|c|c|}
\hline \multirow{2}{*}{$\begin{array}{l}\text { S1. } \\
\text { No }\end{array}$} & \multirow{2}{*}{$\begin{array}{c}\text { Profile } \\
\text { Characteristics }\end{array}$} & \multirow{2}{*}{ Category } & \multicolumn{2}{|c|}{ Amaranthus } & \multicolumn{2}{|c|}{ Vegetable cowpea } \\
\hline & & & Frequency & Percentage & Frequency & Percentage \\
\hline \multirow{9}{*}{2.} & \multirow{9}{*}{ Education } & Illiterate & 4 & 8.89 & 3 & 6.67 \\
\hline & & & 12 & 26.67 & 13 & 28.89 \\
\hline & & & 13 & 28.89 & 15 & 33.33 \\
\hline & & & 13 & 28.89 & 9 & 20.00 \\
\hline & & & 3 & 6.67 & 5 & 11.11 \\
\hline & & $\begin{array}{l}\text { Primary } \\
\text { school }\end{array}$ & 12 & 26.67 & 13 & 28.89 \\
\hline & & \begin{tabular}{|l|} 
High \\
school
\end{tabular} & 13 & 28.89 & 15 & 33.33 \\
\hline & & \begin{tabular}{|l|} 
Higher \\
secondary \\
school \\
\end{tabular} & 13 & 28.89 & 9 & 20.00 \\
\hline & & $\begin{array}{l}\text { College } \\
\text { education }\end{array}$ & 3 & 6.67 & 5 & 11.11 \\
\hline \multirow{3}{*}{3.} & \multirow{3}{*}{$\begin{array}{l}\text { Experience } \\
\text { in vegetable } \\
\text { cultivation }\end{array}$} & Low & 5 & 11.11 & 1 & 2.22 \\
\hline & & Medium & 15 & 33.33 & 18 & 40 \\
\hline & & High & 25 & 55.56 & 26 & 57.78 \\
\hline \multirow{3}{*}{4.} & \multirow{3}{*}{$\begin{array}{l}\text { Area under } \\
\text { vegetable } \\
\text { cultivation }\end{array}$} & $\begin{array}{l}\text { Low (Up } \\
\text { to } 0.1 \mathrm{Ha})\end{array}$ & 17 & 37.78 & 9 & 20.00 \\
\hline & & $\begin{array}{l}\text { Medium } \\
(0.1-0.4 \\
\mathrm{Ha})\end{array}$ & 27 & 60.00 & 28 & 62.22 \\
\hline & & $\begin{array}{l}\text { High (> } \\
0.4 \mathrm{Ha})\end{array}$ & 1 & 2.22 & 8 & 17.78 \\
\hline \multirow{3}{*}{5.} & \multirow{3}{*}{$\begin{array}{l}\text { Contact with } \\
\text { extension } \\
\text { agency }\end{array}$} & Low & 10 & 22.22 & 5 & 11.11 \\
\hline & & Medium & 27 & 60.00 & 31 & 68.89 \\
\hline & & High & 8 & 17.78 & 9 & 20.00 \\
\hline \multirow{3}{*}{6.} & \multirow{3}{*}{$\begin{array}{l}\text { Scientific } \\
\text { orientation }\end{array}$} & Low & 9 & 20.00 & 10 & 22.22 \\
\hline & & Medium & 26 & 57.78 & 29 & 64.44 \\
\hline & & High & 10 & 22.22 & 6 & 13.33 \\
\hline
\end{tabular}


Table 1 contd.

\begin{tabular}{|c|c|c|c|c|c|c|}
\hline \multirow{2}{*}{$\begin{array}{l}\text { S1. } \\
\text { No }\end{array}$} & \multirow{2}{*}{$\begin{array}{c}\text { Profile } \\
\text { Characteristics }\end{array}$} & \multirow{2}{*}{ Category } & \multicolumn{2}{|c|}{ Amaranthus } & \multicolumn{2}{|c|}{ Vegetable cowpea } \\
\hline & & & Frequency & Percentage & Frequency & Percentage \\
\hline \multirow{3}{*}{7.} & \multirow{3}{*}{ Innovativeness } & Low & 8 & 17.78 & 7 & 15.56 \\
\hline & & Medium & 28 & 62.22 & 27 & 60.00 \\
\hline & & High & 9 & 20.00 & 11 & 24.44 \\
\hline \multirow{3}{*}{8.} & \multirow{3}{*}{$\begin{array}{l}\text { Mass media } \\
\text { exposure }\end{array}$} & Low & 6 & 13.33 & 5 & 11.11 \\
\hline & & Medium & 25 & 55.56 & 32 & 71.11 \\
\hline & & High & 14 & 31.33 & 8 & 17.78 \\
\hline \multirow{3}{*}{9.} & \multirow{3}{*}{$\begin{array}{l}\text { Economic } \\
\text { motivation }\end{array}$} & Low & 6 & 13.33 & 4 & 8.89 \\
\hline & & Medium & 24 & 53.33 & 35 & 77.78 \\
\hline & & High & 15 & 33.33 & 6 & 13.33 \\
\hline \multirow{3}{*}{10.} & \multirow{3}{*}{ Risk orientation } & Low & 4 & 8.89 & 6 & 13.33 \\
\hline & & Medium & 32 & 71.11 & 31 & 68.89 \\
\hline & & High & 9 & 20.00 & 8 & 17.78 \\
\hline
\end{tabular}

Table 2.

Distribution of Farmers According to Their Adoption of the KAU Varieties and Selected Recommended Practices of Amaranthus and Vegetable Cowpea

\begin{tabular}{|l|l|c|c|c|c|c|c|}
\hline \multirow{2}{*}{$\begin{array}{l}\text { S1. } \\
\text { No }\end{array}$} & \multirow{2}{*}{ Category } & \multicolumn{3}{|c|}{ Amaranthus } & \multicolumn{3}{c|}{ Vegetable cowpea } \\
\cline { 2 - 7 } & $\begin{array}{c}\text { Score } \\
\text { range }\end{array}$ & Frequency & Percentage & $\begin{array}{c}\text { Score } \\
\text { range }\end{array}$ & Frequency & Percentage \\
\hline 1. & Low & $<15.25$ & 10 & 22.22 & $\begin{array}{c}< \\
25.60\end{array}$ & 11 & 24.44 \\
\hline 2. & Medium & $\begin{array}{c}15.25- \\
57.78\end{array}$ & 27 & 60.00 & $\begin{array}{c}25.60- \\
74.71\end{array}$ & 26 & 57.78 \\
\hline 3. & High & $>57.78$ & 8 & 17.78 & 74.71 & 8 & 17.78 \\
\hline 4. & Mean & \multicolumn{7}{|c|}{36.51} & & & 50.19 \\
\hline 5. & SD & 21.27 & & & 24.52 \\
\hline
\end{tabular}

A perusal of Table 2 reveals that majority of the amaranthus growers $(60$ per cent) and vegetable cowpea growers
(57.78 per cent) were having medium level in adoption, followed by 22.22 per cent of amaranthus growers and 24.44 
Adoption of Kerala Agricultural University Recommended Practices of Amaranthus and Vegetable Cowpea

Table 3.

Adoption of KAU Varieties and Selected Recommended Practices of Amaranthus among Farmers

\begin{tabular}{|c|l|c|c|}
\hline $\begin{array}{c}\text { S1. } \\
\text { No. }\end{array}$ & \multicolumn{1}{|c|}{ Practice } & Adopted (\%) & $\begin{array}{c}\text { Not adopted } \\
\text { (\%) }\end{array}$ \\
\hline 1 & Variety & 80.00 & 20 \\
\hline 2 & Spacing (30 x 20cm) & 0 & 100 \\
\hline 3 & Application of Nitrogen $(50 \mathrm{~kg} / \mathrm{ha})$ & 22.31 & 77.69 \\
\hline 4 & Application of Phosphorous (50 kg/ha) & 24.84 & 75.16 \\
\hline 5 & Application of Potash (50 kg/ha) & 31.57 & 68.43 \\
\hline 6 & $\begin{array}{l}\text { Application of farmyard manure }(50 \mathrm{t} / \\
\text { ha as basal dose) }\end{array}$ & 71.36 & 28.64 \\
\hline 7 & Application of urea (1\%) after harvest & 0 & 100 \\
\hline 8 & $\begin{array}{l}\text { Application of Malathion against leaf } \\
\text { webber (spray malathion 0.1 \% or dust } \\
\text { malathion 10 \% DP) }\end{array}$ & 0 & 100 \\
\hline
\end{tabular}

per cent of vegetable cowpea growers who were low adopters of the KAU varieties and selected recommended practices of amaranthus and vegetable cowpea. Only 17.78 per cent of the amaranthus growers and vegetable cowpea growers belonged to high adoption category.

The adoption percentage of KAU varieties and selected recommended practices of amaranthus and vegetable cowpea are given in Table 3.

In the case of amaranthus, all the respondents had adopted the practice of direct sowing. The crop was harvested thirty days after sowing for marketing. Thus transplanting was not done. But in KAU (2011), package of practices recommendations for transplant amaranthus was given. So from the above table, it could be seen that practices such as spacing and application of urea $(1 \%)$ after harvest were not adopted by any of the respondents. As much as 80 per cent of the farmers adopted the recommended varieties, Arun and Co - 1 which were well accepted in the study area. But the rest 20 per cent of the farmers cultivated other local and hybrid varieties because according to them, the red colour of Arun variety was gradually reducing which affected the market value of the crop. They also opined that even though the local and hybrid varieties that they cultivated yield better than the recommended varieties, Arun variety tasted well when compared to other varieties. 
Table 4.

Adoption of KAU Varieties and Selected Recommended Practices of Vegetable Cowpea among Farmers

\begin{tabular}{|c|l|c|c|}
\hline $\begin{array}{c}\text { S1. } \\
\text { No }\end{array}$ & \multicolumn{1}{|c|}{ Practice } & Adopted (\%) & $\begin{array}{c}\text { Not adopted } \\
\text { (\%) }\end{array}$ \\
\hline 1. & Variety & 67.54 & 32.46 \\
\hline 2. & Seed rate $(4-5 \mathrm{~kg} / \mathrm{ha})$ & 62.31 & 37.69 \\
\hline 3. & Spacing $(2 \times 2 \mathrm{~m})$ & 36.73 & 63.27 \\
\hline 4. & Application of farmyard manure $(20 \mathrm{t} / \mathrm{ha})$ & 69.14 & 30.86 \\
\hline 5. & Seed inoculation with rhizobium & 33.97 & 66.03 \\
\hline 6. & Application of Nitrogen $(20 \mathrm{~kg} / \mathrm{ha})$ & 42.27 & 57.73 \\
\hline 7. & Application of Phosphorous $(30 \mathrm{~kg} / \mathrm{ha})$ & 38.68 & 61.32 \\
\hline 8. & Application of Potash (10 kg/ha) & 36.52 & 63.48 \\
\hline 10. & $\begin{array}{l}\text { Pest control measures (as recommended } \\
\text { by KAU) }\end{array}$ & 51.10 & 48.9 \\
\hline 11. & $\begin{array}{l}\text { Disease control measures (as recommended } \\
\text { by KAU) }\end{array}$ & 44.36 & 55.64 \\
\hline 12. & Use of Pseudomonas & 64.70 & 35.3 \\
\hline 13. & Application of neem cake & 58.52 & 41.48 \\
\hline
\end{tabular}

Only less than 35 per cent of the respondents applied the recommended dose of NPK fertilizers. Since the crop duration was only one month, the amount of fertilizers applied by the farmers was less than the recommended dose. About 71.36 per cent of the farmers applied the recommended dose of farm yard manure which constituted poultry manure and cow dung.

Malathion spray which was recommended under severe conditions of leaf webber attack was not practiced by any respondent. Instead of that, other powerful chemicals such as Radar (Bifenthrin) were used by some farmers.

From Table 4, it could be seen that about 67.54 per cent of the commercial vegetable cowpea cultivators adopted the recommended varieties. Among them, Vellayani Jyothika was adopted by 47.03 per cent, Lola by 9.21 per cent, Vyjayanthi by 4.3 per cent and Githika by 7 per cent. About 33 per cent adopted other local, Hybrid and selection varieties. Lola and Vyjayanthi were the only two varieties which could withstand the extreme summer prevalent during April - May months. 
Adoption of Kerala Agricultural University Recommended Practices of Amaranthus and Vegetable Cowpea

Table 5.

Relationship between the Profile Characteristics of the Respondents and Adoption of KAU Varieties and Selected Recommended Practices of Amaranthus and Vegetable Cowpea

\begin{tabular}{|c|l|c|c|}
\hline \multirow{2}{*}{ S1. No. } & \multicolumn{2}{|c|}{ Profile characteristics } & \multicolumn{2}{c|}{ Correlation coefficient (r) } \\
\cline { 3 - 4 } & & Amaranthus & Vegetable Cowpea \\
\hline 1 & Age & -0.229 & 0.099 \\
\hline 2 & Education & 0.041 & $\mathbf{0 . 3 6 5 ^ { * }}$ \\
\hline 3 & Experience & -0.055 & 0.077 \\
\hline 4 & Area under cultivation & -0.203 & -0.270 \\
\hline 5 & Contact with extension agency & $\mathbf{0 . 4 9 8 * *}$ & 0.152 \\
\hline 6 & Scientific orientation & $0.302^{*}$ & $0.442^{* *}$ \\
\hline 7 & Innovativeness & $0.345^{*}$ & $0.326^{*}$ \\
\hline 8 & Mass media exposure & $\mathbf{0 . 4 2 8 * *}$ & 0.179 \\
\hline 9 & Economic motivation & 0.146 & 0.127 \\
\hline 10 & Risk orientation & -0.212 & -0.126 \\
\hline
\end{tabular}

*Significant at $5 \%$ level, ** Significant at $1 \%$ level

Only 62.31 per cent adopted the recommended seed rate and about 69.14 per cent adopted the recommended dose of farmyard manure. Adoption percentage of recommended spacing was only 36.73 per cent because majority of them practiced closer spacing to get increased yield. Seed inoculation with rhizobium was done by only 33.97 per cent. Use of rhizobium was less mainly due to the non - availability of the same. Also, most of the farmers were not exposed to the utility of rhizobium.

The percentage of respondents who adopted $\mathrm{N}, \mathrm{P}$ and $\mathrm{K}$ fertilizers were $42.27,38.68$ and 36.52 respectively which was less than 50 per cent. The rest adopted higher than the recommended dose. About 51 per cent and 44 per cent of the respondents had taken recommended control measures against pests and diseases respectively. Adoption of Pseudomonas was 64.70 per cent and that of neem cake was 58.52 per cent.

\section{Relationship between Profile characteristics and Adoption}

In the case of amaranthus and vegetable cowpea farmers, scientific orientation and innovativeness were found to have a significant and positive relationship with adoption (Table 5). Farmers who were scientifically oriented 
had correct perception about the new technologies. The correct knowledge helped to create a favourable attitude towards the improved technologies which led to their adoption. Also, innovative farmers had more knowledge about the recommended practices which led to better adoption of the same.

In the case of amaranthus growers, contact with extension agency and mass media exposure had a significant and positive relationship with adoption other than scientific orientation and innovativeness. Majority of the farmers had contact with extension agencies, attended various trainings conducted by Krishi Bhavans and participated in various extension programmes. These would have increased their level of awareness and knowledge and developed a favourable attitude leading to adoption.

In the case of vegetable cowpea farmers, education exhibited a significant and positive relationship with adoption. Through education, level of knowledge of the farmers might have enhanced which resulted in better adoption. Also, educated farmers had an opportunity to adopt the KAU practices because of their greater exposure and interaction within and outside the social system.
So, it could be concluded that direct and indirect effects of education might have contributed to the positive and significant relationship with adoption.

\section{CONCLUSION}

The adoption of KAU practices of amaranthus and vegetable cowpea in Thiruvananthapuram district was found to be medium. Adoption level of the recommended KAU practices of amaranthus and vegetable cowpea could be increased by providing the farmers proper awareness and training which would help them in improving the productivity.

\section{REFERENCES}

Chattopadhyay, S.N. (1963). A study of some psychological correlates of adoption of innovation in farming. Unpublished Ph.D. thesis, IARI, New Delhi.

KAU [Kerala Agricultural University]. (2011). Package of Practices Recommendations: Crops (14 $4^{\text {th }}$ Ed.). Kerala Agricultural University, Thrissur.

Singh, K.M.P. \& Singh, R.P. (1967). Ginger cultivation in Himachal Pradesh. Indian Farming. 30(11), 25-36. 